\title{
EFL Teaching and Reform in China's Tertiary Education
}

\author{
Zengtao Zhao \\ School of Humanities \& Social Science, University of Newcastle, Newcastle, NSW, Australia \\ Email: ztaozhao@hotmail.com
}

\begin{abstract}
When talking about English, learners as well as teachers and linguists, will always couple it with EFL/ESL. Hereinafter, a tentative discussion will be given to the unsatisfactory status quo of EFL at China's universities and colleges, especially Shandong University where the author has been worked. In Addition, this paper will also gives a further detailed discussion on the reform of EFL teaching carried out by Shandong University, for the sake of better achieving expected teaching objectives and meeting the needs of the English learners of the author's home country.
\end{abstract}

Index Terms-EFL, teaching \& reform, China's tertiary education

\section{INTRODUCTION}

In both the West and China, recorded foreign language activities can be traced back to several thousand years ago. Undoubtedly, the actual starting point of human beings' foreign language practice occurred long before people began to record them by written words. As long as people of a languages or a nation who are unlearned to other languages and need to communicate with people of other nations, other than getting assistance from translators or interpreters, language acquisition is the only means left for them to depend on. Before English obtained the mother tongue's status formally during Henry V's time (1387-1422), teaching of Latin and French had long been existed in Britain for at least one thousand years; similarly, in the long history of China's civilization, foreign language teaching in a large scale commenced about two thousand years ago when Buddhist works in Sanskrit were introduced into China's Han Dynasty (Ma, 2006).

China, in the past several decades, especially after the open-door policy was formally carried out about 30 years ago, through increasingly educational budget as well as higher facility investment, has established a full set of public English teaching system from elementary education to tertiary education. At the same time, various teaching theories and methodologies, including those on English as second/foreign language, are introduced to Chinese language teaching specialists, governmental policy makers and students of different levels.

Nevertheless, China's EFL Education at tertiary level is still being guided by some out-of-date guidelines, sometimes being entitled 'Three Old Centers', namely, teacher-centeredness, grammar-centeredness and test-centeredness/testorientedness, which have been proved to be inefficient to achieve an ideal EFL result in China's College English Education (Hao, 2003).

So in this study, the author aims to make a tentative discussion on the problems existing in China's EFL teaching at university and college level, relevant teaching reforms that have been carried out in recent years and the author's own opinions on these reforms, under the guidance of new theories on EFL teaching and with the assistance of the author's experience of teaching lectures such as 'College English' and 'Translation Theory and Practice' at Shandong University, China.

\section{LITERATURE REVIEW}

The teacher-centered mode of EFL teaching that has been dominated China's schools at all levels, certainly including the tertiary level, for decades, mainly lays its theoretical basis on behaviorist linguistic theories. Behaviourism, as John Woollard says in his book Psychology for the Classroom: Behaviourism, is "one of the earliest established theories that had a direct and profound impact upon education, has a special place in the history of psychology. Its heyday was in the first half and middle of the twentieth century but became overshadowed by the influence of the cognitivist and social constructivist explanations of learning that continue to dominate the methods of experimentation and the principles of pedagogy to this day" (Woollard, 2010, p. 21). According to behaviourism, which was the dominant theory during the first half of the $20^{\text {th }}$ century, human beings are conditioned to learn many forms of behaviour, including language, through the process of training, imitation and reinforcement. In such a process, one behaviour is a response that has been triggered off by a stimulus, and then through repeating this stimulus-and-response process, at last this behaviour is firmly formed. Accordingly, teacher-centered EFL teaching approach regards language learning as a process of habit formation, in which new knowledge, essentially a new behaviour, is reinforced and ultimately acquired through appropriate and continuous repetition, as well as controlled instruction. In behaviourists' eyes, the essence of the 
mastery of a second language is to establish fixed stimulus-response chain for a given language feature through imitation and reinforcement. So quietly naturally, the traditional teacher-centered EFL teaching approach merely regards students as passive and docile participants in the whole process of learning.

The traditional teaching approach mentioned above also owes much to structuralist linguistics, especially the American Bloomfieldian School. According to this school's points of view, any human language is constructed into a hierarchical system in which all grammatical elements of different levels such as phonemes, morphemes, words, phrases, clauses, are connected linearly but essentially combined hierarchically, by fixed grammatical rules. Influenced by American Structuralism, traditional EFL teaching approaches, especially the Grammar Translation Approach, also lay much emphasis on grammar drill in EFL class. In Teaching Across Cultures: Considerations for Western EFL teachers in China, the authors Degen Tang \& Absalom Doug quotes McKnight's comment on Chinese methods of EFL teaching:

"While the currently fashionable Western 'communicative approaches' to English language teaching are known and used in some Chinese institutions, the dominant teaching strategy remains the "grammar translation approach"... Our Western methodology textbooks reject this as an outdated and discredited approach to language teaching and learning. It is perhaps surprising, therefore, that so many Chinese students of English have achieved such a good command of the language using this approach" (McKnight, 1994, pp. 46-7).

Actually, though many Chinese college students can get high score or even full mark in any kinds of English exams, most of them are unable to make simple conversations with other Chinese or foreigners in English, or describe basic daily affairs, since traditional EFL teaching approaches only produce dumb English learners. As a result, teachercentered EFL teaching approaches cannot meet the needs of both students and society and the requirements of both Ministry of Education and universities.

According to an investigation made by Qimin Wang, out of the 293 informants he has investigated, "88\% are unsatisfied with the College English teaching and 50\% even lose interest in English after two-year study of College English. After two years' study, 22\% informants still have difficulty in understanding teacher's instruction in English. $30 \%$ can not speak English, 58\% are not able to speak with foreigners about daily affairs, $22 \%$ have difficulty in writing and only $25 \%$ can read some articles of medium difficulty level" (Wang, 2005, pp. 10-26).

In the following part of this thesis, the author intends to give a more detailed discussion on creative reforms on EFL education made by some universities in China, especially the reform of College English syllabus and courses to undergraduates of non-English majors carried out by Shandong University, where the author has studied and then worked for years.

\section{A Case Study: College English Teaching and Reform at Shandong University}

At China's universities and colleges, the College English course, i. e. the tertiary-level EFL course, is one of the most important compulsory courses. Getting a passing score in this course is one precondition for Chinese college students to obtain bachelor degree. On top of it, majority of China's tertiary educational institutes require college students to take part in the College English Band/Level 4 Examination sponsored by China's Ministry of Education. Students will also be deprived of the right to be granted degrees if they fail in this exam. Many employers also regard the certificate of a College English Band 4 or 6 a pivotal criterion to judge an applicant's competence.

But the reality can discourage even the most optimistic persons---the traditional EFL teaching model only produces a large number of 'high score but low competence' students who only are good at using dumb English---even though the governments of different levels and universities supply innumerable money, facilities and faculty to College English education. In the author's opinion, this unfavourable status quo can find its answer from the following four factors:

(1) The Influence of Traditional EFL Teaching Approaches

Heavily influenced by traditional EFL teaching approaches such as grammar translation approach and audiolingual approach, in China's college English class, unquestionably teacher is the dominant role both in class activities and plan of teaching content. Compared with teacher' role, students only act as supporting roles who have few chance to speak in the class, being imbued with amounts of knowledge passively. Besides bahaviourism's reinforcement of stimulusresponse chain mentioned above, cognitive learning theory advocated by American scholars such as Chomsky, Ausubel and Neisser, argues that the main task of EFL learning is to grasp various rules that guide the formation and usage of words and sentences. Thus, much attention is paid to the drill of grammatical rules, which have no much value in daily communication.

(2) Factor of Examination and Employment

Since the certificate of College English Band 4 or 6 is required by universities and employers, most Chinese college students spend much time on the preparation of this exam. Objectively speaking, China's College English Examination encourages universities and students to pay more attention to EFL teaching and learning, thus to a certain degree guaranteeing the quality of college EFL teaching. On the other hand, this exam also hinders students from achieving a balanced development of different skills, namely, speaking, writing, reading, listening and translating, since it gives a priority to some of these skills.

(3) Factors of EFL teachers 
It can not be denied that the factors related to a teacher, such as his or her personal charm, morality, knowledge, teaching attitude, exert heavy influence on the effect of EFL teaching and learning. Due to historical reasons, the majority of college EFL teachers are the 'product' of traditional EFL teaching approaches. So quite naturally, they are inclined to cling to these old teaching approaches. Even worse, many of them are not good at oral English since the whole country was short of facilities and qualified teachers decades ago. As a result, they are quite reluctant to adopt newer but more challenging methods.

(4) Student's Learning Attitude and Motivation

Over the past several decades, along with the boom of student-centered approaches, research on 'learning motivation' developed gradually. Students' 'learning motivation' can be further divided into two categories, namely, the interior motivation and exterior motivation, among which the first is more stable and lasts much longer. Unlike the interior motivation, the exterior motivation is much easier to be disturbed by various factors. Taking China's EFL learning atmosphere as an example, it is not so ideal for Chinese EFL learners since Chinese is a very different language to English.

With regard to the extent problems in China's EFL teaching, Shandong University, where the author has worked as a college English teacher for several years, makes a series of thorough reforms on EFL teaching, which can be summarized as follow:

(1) Graded Class of College English

Taking consideration of the diversified EFL competence of the freshmen students, Shandong University requires all freshmen to take a displacement exam at the very beginning of their enrolment. Then depending on this exam and the English score of College Entrance Examination, freshmen students will be grouped into English class of three levels. For instance, students with high scores of these two exams mentioned above will attend the higher-level class, in which lectures delivered will be more difficult and faster. In this way, more targeted teaching strategies that meet the needs of different levels can be carried out.

(2) Transferring from Lower-level Class to Higher Ones

To motivate the students' interest to college English learning, students who perform well in their later English study will have the chance to transfer to higher-level class.

(3) Setting up Unattached Listening \& Speaking Course

In order to strengthen students' speaking and listening skills, Shandong University offers students of non-English disciplines independent listening \& speaking course, which has always been attached to college English course mainly in a reading and writing manner before.

(4) Specialized English Elective Courses for Higher-grade students

After two-year study of college English courses, the third-year and forth-year students can still enrol English elective courses that formerly are only accessible to student of English discipline, such as American Literature, Lexicology, Semantics, Translation Theory and Practice, so that their English competence can be further deepened and enhanced.

(5) Unhooking Certificate of College English Exam with Degree Awarding

According to the old regulations of degree awarding, if students fail to get at least a passing grade in National College English Test Band 4 (CET-4) in their four-year bachelor's programme, they will be deprived of the right to get a bachelor degree, only certificate of graduation granted. As a result, college English teaching is doomed to be an examoriented education. For the sake of settling this problem, Shandong University abolishes this rule at last.

(6) A New Syllabus for Larger Vocabulary

As the old syllabus of college English regulated, the minimum vocabulary is just about 5,000 words. But we know that a person needs to master about 30,000 to 50,000 words if he or she wants to understand the articles in Washington Post, Sydney Herald or Times. With regard to this problem, the University sets up optional course to enhance reading and vocabulary in the third academic year, which aims to increase students' storage of English words to around 80,000 words.

\section{A SAMPLE LECTURE: AMERICAN DREAM}

Compared with the traditional EFL teaching approaches such as grammar translation approach or audiolingual approach, a comprehensive application of the strong points of different approaches, including the direct method, audiolingualism, Audio-video approach etc., acts as a the most ideal way for facilitating the training of various language skills especially listening and speaking, having received high praise from both teachers and students. In the following section, the author of this article, based on his own teaching experience, will give a further discussion on Shandong University's EFL reform through a sample lecture, in which necessary adaptations or amendments having been made, so as to meet the rapid-changing world, guided mainly by this comprehensive and multivariate approach mentioned above.

\section{Teaching Objectives}

The basic or the lower objective of this 'comprehensive' teaching approach is to enable the learners of English to communicate with others fluently or at least efficiently, through reinforced training in listening comprehension, accurate pronunciation, dialogue and conversation, and reading comprehension. For achieving this aim at last, this approach follows a fixed sequence in the mastery of the four basic language skills, that is, beginning with listening and 
speaking, and then using these two skills as a foundation for grasping the left two basic skills, reading and writing. As a higher objective, this approach aims to help the students to obtain an almost equal ability that those native speakers own.

\section{Main Teaching Principles}

Inheriting much from the natural approach, direct method, audiolingualism etc., and drawing on useful theoretical arguments from structural linguistics and behavioral psychology, this integrated approach forms its own distinctive teaching characteristics, the most typical ones of them are shown as follow:

1) Giving a priority to the training of communicative ability;

2) Separation of language skills into four basic ones, namely, listening, speaking, reading, and writing, with an obvious emphasis on the teaching and mastery of listening and speaking before that of reading and writing;

3) Discouraging the use of native language in the classroom;

4) Limited teaching of vocabulary at the beginning stages of learning;

5) Errors should try to be avoided and corrected;

6) Use of dialogues as the chief means to practice spoken English;

7) Emphasis on certain teaching techniques, such as imitation, repetition, memorization, positive reinforcement, and pattern drills;

8) Making full use of audiovisual facilities such as multi-media classroom, language laboratory;

9) Teaching of grammatical rules in a scientific and inductive way.

\section{Typical Teaching Techniques \& Class-time Activities}

In a typical classroom course of this different-approach-combined teaching approach, dialogues between students as well as between lecturer and students, and pattern practice mainly on grammatical rules and useful expressions are the dominating on-class activities, which take a lion's the class time. In order to achieve a qualified communicative ability, this approach insists on the following teaching techniques to be used in classroom:

(1) Imitation: In this kind of training, students are required to imitate, not only what teacher has said but also the teacher's speaking speed, intonation etc., as accurately and quickly as possible, e. g.:

$$
\text { Teacher Student(s) }
$$

Is this a koala? $\nearrow$ (pause) An Australian koala? $\nearrow \rightarrow \quad$ Is this a koala? $\nearrow$ (pause)

An Australian koala? $\nearrow$

(2) Repetition: In terms of manner, this drill is similar to imitation, but whose main aim is to master the new knowledge through repeated imitation. $\mathrm{T}$

$$
\mathrm{S}_{\mathrm{s}}
$$

I have a female koala. $\rightarrow \quad$ [I have a female koala. $]_{n}$

(3) Minimal Pairs for Phonetic Drill: In this drill, pairs of words that only differ in one phoneme are provided to students, they are asked to find the difference at first, and then to make a follow reading, at last to produce the appropriate sounds on themselves.

ship---sheep big---pig bit---beat

mug---mud lid---lead plum---plug

(4)Variation: This kind of drill includes substitution, conversion, and expansion; through this sequence, increasing scale of difficulty is imposed upon students' learning.

A. Substitution: It consists of mono-component and multi-component substitutions. In this drill, students are required to repeat the lines of a dialogue, then replacing the old information, by the cues offered, i. e. the new information, in their proper places. Its major purpose is to let students to practice finding suitable words and then filling proper slots of sentences.

(a) Mono-component Substitutions:

T: We will go to cinema tomorrow. The cue is fish.

S: We will go fishing tomorrow.

(b) Multi-component Substitutions:

$$
\mathrm{T} \quad \rightarrow \quad \mathrm{S}_{1} \rightarrow \mathrm{S}_{2}
$$

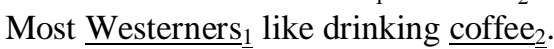

$$
\begin{aligned}
& \mathrm{S}_{1} \rightarrow(\text { Cue) Easterner; tea } \\
& \quad \mathrm{S}_{2} \rightarrow \text { Most Easterners } \underline{\underline{E}}_{\underline{1}} \text { like drinking tea } \underline{\underline{\text { tea }}} .
\end{aligned}
$$

B. Conversion:

(a) Pure Conversion: It mainly includes semantic changes such as the switch between active and passive voice, and structural changes such as the addition or deletion of some sentential components, or both.

- In our department, he is the youngest teacher. (Declarative Sentence)

$\rightarrow$ In our department, is he the youngest teacher? (Interrogative)

- In our department, he is the youngest teacher. (Affirmative)

$\rightarrow$ In our department, he is not the youngest teacher. (Negative)

- In our department, he is the youngest teacher. (Declarative)

$\rightarrow$ In our department, who is the youngest teacher? (Interrogative) 
(b) Sentence Completion: After hearing an utterance that is complete except for one word, students are required to find a proper word for the slot and then repeat the utterance in its complete form.

$\mathrm{T}$ : A friend in need is a friend

Ss: A friend in need is a friend indeed.

C. Expansion:

(a) Pure Expansion: This drill helps students to produce longer sentences gradually and achieve fluency reliably. Foe instance:

T: They go out to eat. Ss: They go out to eat.

T: At weekends. Ss: They go out to eat at weekends.

T: Often. $\quad$ Ss: They often go out to eat at weekends.

(b) Clause Combination: This drill gives chances to students to practice combining two simple sentences into a longer one, either a compound or a complex one.

T: I am free tomorrow. Come to see you.

Ss: I will come to see you again tomorrow if I am free.

(5) Question-and-Answer Drill: This drill asks students to respond teacher's questions swiftly. It is also possible for students to ask questions by some cues, offered by teachers.

$\mathrm{T}$ : Who is the first president of USA?

$\mathrm{S}_{\mathrm{s}}$ George Washington.

T: Sun Yat-sen

$\mathrm{S}_{\mathrm{s}}$ He is the first president of the former Republic of China.

(6) Description or Dialogue on the Pictorial Information Provided: To cite an example, according to the following picture, students are required to describe the position of the stuff in a classroom.

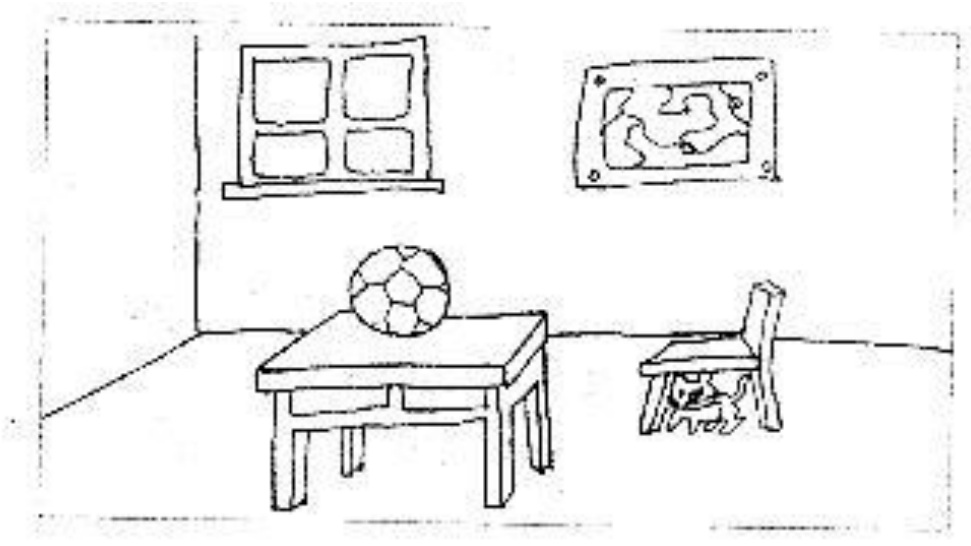

Figure-1

\section{A Sample Lecture: American Dream}

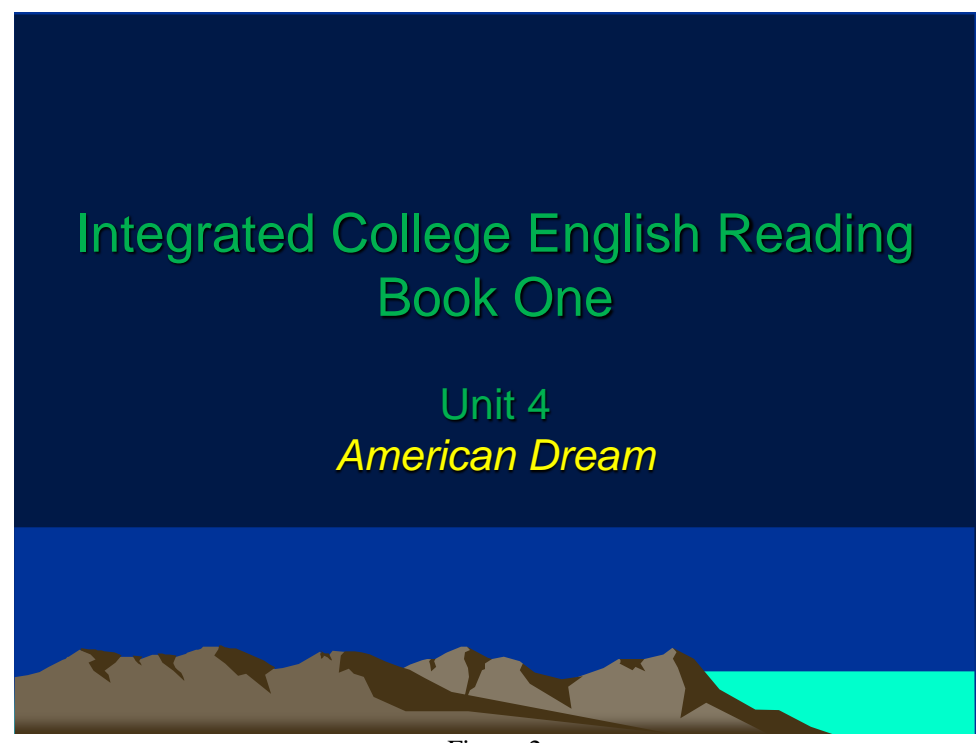

Figure-2 
To help readers to get a more ostensive, tangible view on this 'Comprehensive Approach' language teaching, in this section of the paper, the author chooses a lesson of College English which he has taught as an example. Generally speaking, in a typical lesson of this approach, the whole teaching procedure can be divided into four main steps, successively: recognition, imitation \& repetition, pattern drills, and follow-up activities. But here a detailed specifications as well as constructions of the lesson American Dream serves as a better way to highlight the main features of this approach.

\section{Lecture: American Dream}

(Two connected classes, each 50 minutes long, with a 10-min rest in between)

(1) Pre-class Tasks (homework of the previous class):

a.) What is an "American Dream"?

b.) How can a person succeed in a career?

c.) Hard work and great ambition, which is more important, or both?

(2) Warm-up Activities (up to 20 minutes):

At the beginning of the first class, a couple of students are asked to make a short presentation on the above topics listed. Each student's presentation should be no less than 5 minutes. After the presentations, teacher will give an overall summary and comment.

(3) New Words Learning \& Text Explanation (up to 40 minutes):

One point needs to be particularly stressed is since the text is quite long, usually it is divided into two parts for two 2hour lessons. When explaining the new words, expressions, and the main body of the text, teacher should only use the target language or try to avoid using the mother tongue. During the delivering, a reciprocal communication between lecturer and students is strongly encouraged.

(4) Pattern Drills (up to 20 minutes):

Depending on various useful teaching techniques used by different teaching approaches, the lecturer supervises the students' learning and mastering of the new expressions and useful grammatical structures learnt just now.

(5) Follow-up Activities (up to 20 minutes)

As a device to enhance the effect of learning and another chance for spoken English practice, some students are required to make a role play or even a cosplay, based on the text just learnt, in their own words instead of a rote memory.

(6) Homework:

Off the class, the relevant exercises attached to the unit are required to fulfill as the homework so that the next time it can be used as the material for on-class training and an assessment of the learners' achievement as well.

\section{CONCLUSION}

As a summary, the above-mentioned student-centered and communication-oriented EFL teaching reform carried by Shandong University does have achieve great success, which has been demonstrated by relevant statistics from different angles. Nevertheless, the author of this paper personally thinks that still some improvements should be made. At first, besides the augmentation of vocabulary, research on the frequency and usage of words is also of equally importance; secondly, for realizing a balanced development, the author hopes that Shandong University's college English final-term exam would adopt the score allocation model being used in IELTS and new TOFEL; last but not least, the mode of graded class should be further improved since it potentially discourages those students whose English are not good before entering into university.

\section{REFERENCES}

[1] Brown, H. Douglas. (1994). Teaching by Principles: An interactive approach to language pedagogy. New York, USA: Prentice Hall Regents.

[2] Brown, H. Douglas. (2000). Principles of Language Learning and Teaching. London, UK: Longman Inc.

[3] Cohen, A. D. (2000). Strategies in Learning and Using a Second Language. Beijing, China: Foreign Language Teaching and Research Press.

[4] Ding, Yanren. (2004). Second Language Acquisition and Foreign Language Learning. Shanghai, China: Shanghai Foreign Language Education Press.

[5] Ellis, R. (1994). The Study of Second Language Acquisition. Oxford, UK: Oxford University Press.

[6] Gui, Shicun. (1992). Chinese Students' Psychology on English Learning. Changsha, China: Hunan Education Press.

[7] Hao, Xingyue. (2003). "Educational Conflicts between the Chinese Immigrants and ESL teachers in Western Countries", Journal of Kuming University of Science and Technology. 3 (1): 96-99.

[8] Harmer J. (2000). How to Teach English. Beijing, China: Foreign Language Teaching and Research Press.

[9] Hedge, T. (2002). Teaching \& Learning in the Language Classroom. Shanghai, China: Shanghai Foreign Language Education Press.

[10] Hughes, Arthur. (2003). Testing for language teachers ( $2^{\text {nd }}$ ed.). Cambridge, UK: Cambridge University Press.

[11] Jiang, Zukang. (2002). On the Learning Style in ESL/EFL Classroom. Beijing, China: Foreign Language Teaching and Research Press.

[12] Ma, Zuyi. (2006). A History of Translation in China. Wuhan, China: Hubei Education Press. 
[13] McKnight, A. (1994). “Chinese Learners of English: A different view of literacy?”, Australian Journal for Adult Literacy Research and Practice. 4 (2). 39-52.

[14] Nation, Paul. (1990). Teaching and Learning Vocabulary. New York, USA: Newbury House.

[15] Neisser, Ulric. (1967). Cognitive Psychology. New York, USA: Appleton-Century-Crofts.

[16] Paulston, C. B. (1992). Linguistic and Communicative Competence: Topic in ESL. Philadelphia, USA: Multilingual Matters Ltd.

[17] Reid. M. (2002). Learning Style in the ESL/EFL Classroom. Beijing China: Foreign Language Teaching and Research Press.

[18] Skehan, P. (1998). A Cognitive Approach to Language Learning. Oxford, UK: Oxford University Press.

[19] Spolsky, B. (2000). Conditions for Second Language Learning. Shanghai, China: Shanghai Foreign Language Education Press.

[20] Wang, Qiming. (2005). Towards an Integrated Model of College English Teaching. Wuhan, China: Hubei Education Press.

[21] Wenjing, Li. (2010). "Encouraging Active Learning Method in EFL Classroom”, Overseas English. 13 (5): 71-72.

[22] Woollard John, (2010). Psychology for the Classroom: Behaviourism. London, UK: Routledge.

[23] Xia, Jimei. (2003). The Theory and Practice on the Design of Contemporary Foreign Language Courses. Shanghai, China: Shanghai Foreign Language Education Press.

[24] Zhao, Yong. (2007). “On Krashen's Theory of Second Language Acquisition”, Journal of Shijiazhuang University. 9 (5): $94-$ 96.

[25] Zhao, Zengtao. Assignment 2 of EDUC 6025 TESOL Curriculum and Methodology. 2010: pp. 2-3. University of Newcastle, NSW, Australia.

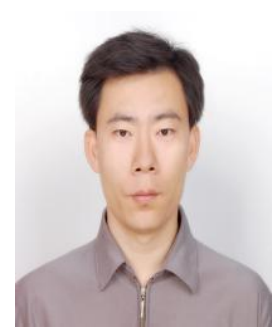

Zengtao Zhao, born on June 6,1976, has got his master degree of arts specializing in English language \& literature from Shandong University in 2003 and then been worked at School of Foreign Languages and Literature, Shandong University as a lecturer of college English for years, is currently a $\mathrm{PhD}$. candidate majoring in modern languages at University of Newcastle, Australia. 